\begin{tabular}{|c|c|c|c|c|}
\hline $\begin{array}{c}\text { Prosiding Penelitian \& } \\
\begin{array}{c}\text { Pengabdian Kepada } \\
\text { Masyarakat }\end{array}\end{array}$ & $\begin{array}{c}\text { e ISSN : 2581-1126 } \\
\text { p ISSN : 2442-448X }\end{array}$ & Vol 6, No: 3 & Hal: 202 - 215 & Desember 2019 \\
\hline
\end{tabular}

\title{
PELAKSANAAN PROGRAM PENGEMBANGAN MASYARAKAT OLEH PT PERTAMI NA DI DESA PANGKALAN BABAT, KECAMATAN RAMBANG DANGKU, MUARA ENI M DI SUMATERA SELATAN
}

\author{
Ade I rma Sakina' ${ }^{1}$, Nur Aftina², Salwa Azaria ${ }^{3}$, Santoso Tri Raharjo ${ }^{4}$, Risna \\ Resnawaty 5 \\ 1, 2, 3 Program Studi Sarjana I Imu Kesejahteraan Sosial Universitas Padjadjaran \\ 4, 5 Pusat Studi CSR, Kewirausahaan Sosial \& Pemberdayaan Masyarakat, Universitas Padjadjaran \\ (ade16014@mail.unpad.ac.id; nur6014@mail.unpad.ac.id, \\ salwa16004@mail.unpad.ac.id, santoso.tri.raharjo@unpad.ac.id; risna.resnawaty@unpad.ac.id)
}

\begin{abstract}
ABSTRAK
Corporate Social Responsibility (CSR) pada peningkatan ekonomi yang berkelanjutan sebagai bentuk komitmen perusahaan, bahwa adalah komitmen perusahaan atau dunia bisnis untuk berkontribusi dalam pengembangan ekonomi yang berkelanjutan dengan memperhatikan tanggung jawab sosial perusahaan dan menitikberatkan pada keseimbangan antara perhatian terhadap aspek ekonomis, sosial, dan lingkungan. Seperti PT.PERTAMINA yang melaksanakan CSR di Desa Pangkalan Babat, Kecamatan Rambang Dangku, Muara Enim Di Sumatera Selatan. Perusahaan energi tersebut melaksanakan program CSR pada bidang pengembangan masyarakat. Artikel ini menggunakan kajian metode penelitian menggunakan kajian pustaka dan hasilnya menunjukkan bagaimana hubungan antara program CSR PT PERTAMINA tersebut dengan konsep CSR dan pengembangan masyarakat.
\end{abstract}

Kata Kunci: Corporate Social Responsibility, pengembangan masyarakat, PT PERTAMINA

Corporate Social Responsibility (CSR) on economic improvement supported by corporate commitment, corporate or world commitment to contributions in economic development supported by corporate social responsibility and emphasizes balance in relation to assistance to the economic, social and environmental sectors. Such as PT. PERTAMINA which implemented CSR in Pangkalan Babat Village, Rambang Dangku District, Muara Enim in South Sumatra. The energy company is implementing CSR programs in the field of community development. This article uses a study of research methods using a literature review and research results regarding the relationship between PT PERTAMINA's CSR program and the concept of CSR and community development.

Keywords: Corporate Social Responsibility, community development, PT PERTAMINA 


\begin{tabular}{|c|c|c|c|c|}
\hline $\begin{array}{c}\text { Prosiding Penelitian \& } \\
\begin{array}{c}\text { Pengabdian Kepada } \\
\text { Masyarakat }\end{array}\end{array}$ & $\begin{array}{c}\text { e ISSN : 2581-1126 } \\
\text { p ISSN : 2442-448X }\end{array}$ & Vol 6, No: 3 & Hal: 202 - 215 & Desember 2019 \\
\hline
\end{tabular}

\section{PENDAHULUAN}

Provinsi Sumatera Selatan merupakan salah satu daerah yang kaya akan sumber daya alam, khususnya dalam bidang energi seperti tambang batu bara, minyak dan gas bumi (migas). Sebagai wujud dari sebagai bentuk dari pemanfaatan tersebut, pemerintah provinsi Sumatera tersebut, Pemerintah Provinsi Sumsel membuka peluang investasi bagi perusahaan lokal, nasional maupun multinasional untuk menanamkan modalnya dalam bentuk kegiatan eksplorasi dan eksploitasi tambang. Dalam beberapa tahun banyak sekali perusahaan yang bergerak dalam bidang energi migas yang beroperasi dalam menggali tambang migas, minyak dan gas bumi. Investasi dalam berbagai daerah secara tidak langsung telah mendorong pertumbuhan ekonomi, termasuk kawasan pedesaan. Oleh karena itu pertumbuhan ekonomi dapat berdampak pada penyerapan tenaga kerja dan peningkatan taraf hidup masyarakat pedesaan di daerah tersebut. Namun di sisi lain, banyaknya aktivitas ekonomi di daerahnya tidak secara signifikan berpengaruh terhadap peningkatan pendapatan masyarakat, yang terjadi justru menimbulkan ketimpangan sosial, ekonomi dan budaya. Dan kebanyakan penduduk desa masih mengalami kehidupan di bawah garis kemiskinan.

Fenomena ini masih menjadi suatu hal yang biasa di daerah tersebut. Pemerintah dan perusahaan sudah berupaya dengan membuat program pengetasan kemiskinan dan pemberdayaan masyarakat agar tidak adanya ketimpangan di kawasan tersebut. Ketimpangan menjadi salah satu fenomena yang sering terjadi di beberapa tempat, khusunya di kawasan pertambangan. Salah satu kesulitan perusahaan dalam mengatasi kesenjangan adalah karena adanya kegiatan pertambangan dengan menggunakan teknologi tinggi dan karenanya memerlukan sumber daya manusia dengan tingkat kemampuan yang lebih tinggi juga. Kesenjangan ini pula yang melahirkan peluang konflik antara perusahaan dan masyarakat, salah satunya diakibatkan oleh besarnya penduduk miskin di pedesaan. Penduduk miskin di Indonesia cenderung lebih besar berada di pedesaan yang rata-rata penduduknya menggantungkan diri pada sektor agraris. Petani pedesaan sebagian besar hanya memiliki lahan yang sempit, bahkan tidak sedikit yang hanya sebagai buruh tani akibatnya penghasilan yang mereka dapatkan sangat rendah dan mereka inilah yang dikatakan sebagai orang miskin. Selama ini penanganan masalah kemiskinan sudah banyak dilakukan oleh pemerintah melalui berbagai program, seperti Program Inpres Desa Tertinggal (IDT), Program Jaring Pengaman Sosial (JPS), Program Beras Miskin (Raskin), Program Asuransi Kesehatan Masyarakat Miskin (Askeskin), dan melalui P2KP serta program Nasional Pemberdayaan Masyarakat (PNPM).

Ternyata banyak program yang sudah dilakukan pemerintah dalam mengetaskan kemiskinan tapi semua program tersebut tidak berjalan dengan baik. Dengan demikian perusahaan memberikan kontribusinya kepada masyarakat dengan membentuk CSR. Achmad Fedyani Saifuddin mengatakan bahwa kemiskinan dan proses pemiskinan terus terjadi, di tandai dengan menurunnya kualitas hidup. Belum berhasilnya program pengetasan kemiskinan telah mendorong perusahaan memberikan kontribusinya dalam bentuk tanggung jawab sosial perusahaan.

Di Indonesia, kewajiban dalam pelaksanaan CSR diatur dalam UU No. 40 Tahun 2007 tentang Perseroan Terbatas serta dalam PPNo. 47 Tahun 2012 tentang Tanggung J awab Sosial dan Lingkungan Perseroan Terbatas. Berdasarkan perundang-undangan tersebut, tanggung jawab sosial dan lingkungan adalah bentuk komitmen perseroan guna berperan serta dalam pembangunan ekonomi yang berkelanjutan, serta meningkatkan kualitas kehidupan dan lingkungan yang bermanfaat bagi perseroan secara internal dan eksternal, komunitas setempat, serta masyarakat secara umum. Program CSR ditujukan agar para pelaku bisnis, baik sektor industri dan korporasi, dapat turut berperan dalam perutumbuhan ekonomi 


\begin{tabular}{|c|c|c|c|c|}
\hline $\begin{array}{c}\text { Prosiding Penelitian \& } \\
\begin{array}{c}\text { Pengabdian Kepada } \\
\text { Masyarakat }\end{array}\end{array}$ & $\begin{array}{c}\text { e ISSN : 2581-1126 } \\
\text { p ISSN : 2442-448X }\end{array}$ & Vol 6, No: 3 & Hal: $202-215$ & Desember 2019 \\
\hline
\end{tabular}

yang sehat, dengan memperhatikan faktor lingkungan hidup. Akan tetapi, dalam kesimpulan penelitian yang dilakukan (Nursahid, 2006) pada tiga perusahaan BUMN, sebagian besar derma atau bantuan sosial diberikan ketika BUMN masih bersifat karitatif (charity) daripada filantropi. Bantuan tersebut masih terfokus pada pemenuhan kebutuhan sesaat dan belum mampu menyentuh aspekaspek strategis ekonomi pembangunan masyarakat disekitar wilayah kerja. Meskipun secara normatif penyelenggaraan CSR didorong oleh kesadaran akan tanggung jawab sosial, di dalam pelaksanaannya masih dibayangi oleh pencitraan positif dari perusahaan saja. Perusahaan secara garis besar belum memiliki sebuah perancaaan strategis atau cetak biru pelaksanaan program yang komprehensif, terhadap pelaksanaan program (Ardianto dkk, 2011). Berdasarkan data yang dihimpun peneliti dari beragam sumber, memberikan gambaran bahwa pelaksanaan CSR di Indonesia sebagian besar masih berupa karitatif dan sebagai ajang pembentukan citra positif perusahaan. Belum sepenuhnya berupa keinginan untuk membangun sebuah perekonomian yang berkelanjutan, pada masyarakat sekitar wilayah operasinya (Ardianto, Elvinaro dkk., 2011). Efek Kedermawawanan Pebisnis \& CSR.. Hal ini sebenarnya merupakan bentuk paling primitif dari pelaksanaan tanggung jawab sosialnya. PT Pertamina sebagai salah satu National Oil Company, memiliki visi sebagai perusahaan World Class yang berkomitmen untuk berkontribusi dalam terwujudnya Sustainable Development Goals (SDGs), salah satu target yang ingin dicapai adalah penurunan kemiskinan dan degradasi lingkungan di negara berkembang. Maka yang menjadi permasalahan dalam penelitian ini adalah bagaimana pelaksanaan program CSR yang dilakukan PT Pertamina, serta melalui indikator apa pelaksanaan program CSR tersebut sesuai dengan asas kebutuhan, manfaat, serta sejauh mana tingkat efisiensi pelaksanaan program dalam melibatkan masyarakat dalam partisipasi terhadap pelakasanaan program.
MDGs merupakan langkah strategis yang ditetapkan di New York, Amerika Serikat pada tahun 2010, dalam pertemuan yang dihadiri oleh pejabat tinggi pemerintah, pebisnis, dan organisasi dunia tersebut menetapkan delapan target yang ingin dicapai dunia pada tahun 2015. Secara garis besar MDGs dimaksudkan untuk mengurangi separuh kemiskinan dan kelaparan pada tahun mendatang. Pihak swasta dan korporasi diikutsertakan dan diupayakan dapat memaksimalkan perannya dalam pelaksanaan tanggung jawab sosial dan lingkungan, dalam bentuk pelaksanaan CSR. Akan tetapi dalam implementasinya, bentuk kewajiban ikut berperan aktif dalam CSR tersebut masih perlu mendapat perhatian kritis. Sebagian besar korporat tetap melaksanaan CSR hanya sebagai bentuk santunan, dengan efek yang sesaat dan masih terpusat pada kebutuhan jangka pendek. Dalam permalasahan tersebut, pelaksanaan CSR yang masih sangat primitif dan menjadi ajang pencitraan korporasi terjebak pada kalimat "charity". Pada gejolak permasalahan itu, tanggung jawab perusahaan BUMN terhadap pembangunan ekonomi sekitar diwujudkan dalam bentuk bina lingkungan, yang kemudian diatur dalam Kepmen BUMN No.236/ MBU/2003. Kepmen tersebut menyatakan bahwa dalam pelaksanaan CSR, perusahaan BUMN wajib melaksanaan program kemitraan dengan UKM, Usaha Skala Kecil, dan program bina lingkungan. Tujuan dari ditetapkannya peraturan tersebut adalah memberikan arah yang jelas, agar perusahaan dapat tetap berkomitmen pada kesepakatan dunia dalam mengentaskan kemiskinan dan pencapaian ISO 26000.

Latar belakang pelaksanaan program CSR PT Pertamina mengacu pada ISO 26000, yaitu konsisten dengan pembangunan yang berlanjutan dan tercapainya kesejahteraan rakyat, mempertimbangkan ekspektasi semua stakeholder, taat hukum dan konsisten dengan norma internasional, dan terintegrasi dengan kegiatan bisnis. Sementara itu, beberapa tujuan yang dijadikan motif pelaksanaan program 


\begin{tabular}{|c|c|c|c|c|}
\hline $\begin{array}{c}\text { Prosiding Penelitian \& } \\
\begin{array}{c}\text { Pengabdian Kepada } \\
\text { Masyarakat }\end{array}\end{array}$ & $\begin{array}{c}\text { e ISSN : 2581-1126 } \\
\text { p ISSN : 2442-448X }\end{array}$ & Vol 6, No: 3 & Hal: 202 - 215 & Desember 2019 \\
\hline
\end{tabular}

secara eksternal adalah memberikan kontribusi dalam perbaikan indeks pembangunan manusia (IPM) Indonesia, melalui pelaksanaan programprogram yang mensukseskan tercapainya MDGs. Sedangkan secara internal pelaksanaan program tersebut adalah membangun hubungan yang harmonis dan kondusif dengan pemangku kepentingan (stakeholder) yang ada, guna turut berkontribusi dalam pencapaian tujuan korporasi terutama dalam membangun reputasi. Visi pelaksanaan program "Menuju Kehidupan Lebih Baik", dengan kriteria pelaksanaan meliputi lima kriteria pelaksanaan, mencakup kepentingan bersama antara pemerintah, komunitas dan perusahaan, serta memenuhi asas manfaat, berkelanjutan pada wilayah di dekat wilayah operasi, publikasi dan mendukung PROPER

\section{PEMBAHASAN}

\section{Konsep Corporate Social Responsibility (CSR) dan Community Development}

Berdasarkan Undang Undang Nomor 40 Tahun 2007 tentang perseroan teratas Bab V Pasal 74, Corporate Social Responsibility (CSR) merupakan "tanggung jawab sosial dan lingkungan“, walaupun tidak dijelaskan secara lebih lanjut pengertian dari tanggung jawab sosial dan lingkungan tersebut. Dalam penjelasan undang-undang tersebut dalam ayat (1), bahwa ketentuan tersebut bertujuan untuk tetap menciptakan hubungan Perseroan yang serasi, seimbang, dan sesuai dengan lingkungan, nilai, norma, dan budaya masyarakat setempat. Wibisono (2007: 8) mengemukakan bahwa: "Corporate Social Responsobility (CSR) secara etimologis diterjemahkan sebagai tanggung jawab sosial perusahaan. Dalam konteks lain, Corporate Sosial Responsibility kadang juga disebut tanggung jawab sosial korporasi, atau tanggung jawab sosial dunia usaha (tansodus)."

Selain sebagai tanggung jawab sosial perusahaan, CSR juga dapat dikatakan sebagai kepedulian organisasi bisnis, seperti yang di ungkapkan oleh Schemerhon, "Corporate Social Responsibility (CSR) sebagai suatu kepedulian organisasi bisnis untuk bertindak dengan caracara mereka sendiri dalam melayani kepentingan organisasi dan kepentingan publik eksternal." Pada pelaaksanannya tujuan program CSR ini ditunjukkan oleh kepentingan pelaku bisnis, program CSR ditujukan agar para pelaku bisnis, baik sektor industri dan korporasi, dapat turut berperan dalam perutumbuhan ekonomi yang sehat, dengan memperhatikan faktor lingkungan hidup. Selain untuk kepentingan bisnis CSR juga ditunjukkan untuk kepentingan masyarakat sekitar. Corporate Social Responsibility (CSR) adalah sebuah komitmen perusahaan atau dunia bisnis dalam memberikan kontribusi terhadap pengembangan ekonomi yang berkelanjutan, dan menitikberatkan pada perhatian aspek ekonomi, sosial, dan lingkungan (Ardianto, 2011)

Selain komitmen untuk memberikan kontribusi pada pengembangan aspek ekonomi, sosial dan lingkungan. CSR juga berkomitmen untuk memberikan sumbangsih berdasarkan apa yang dibutuhkan oleh masyarakat itu sendiri. Seperti yang diungkapkan oleh Kotler dan Lee. Definisi CSR menurut Kotler dan Lee adalah komitmen dari perusahaan untuk meningkatkan kesejahteraan masyarakat dengan menjalankan bisnis yang baik dan sebagai sumbangsih sumber daya yang dibutuhkan oleh masyarakat.

Dalam mempertimbangkan manfaat yang akan diterima oleh perusahaan melalui program CSR. Perusahaan memiliki motif tertentu dalam menjalankan programnya, dan motif tersebut dapat mempengaruhi tingkat program CSR apa yang akan diambil dan diterapkan. Tingkatan-tingkatan dapat dikemukan sebagai berikut:

\section{Corporate Charity}

Corporate Charityini dapat digolongkan sebagai CSR yang dilakukan oleh perusahaan dengan didasarkan pada motif kerikatif (amal). Bentuk kegiatan yang dilakukan oleh perusahaan 


\begin{tabular}{|c|c|c|c|c|}
\hline $\begin{array}{c}\text { Prosiding Penelitian \& } \\
\begin{array}{c}\text { Pengabdian Kepada } \\
\text { Masyarakat }\end{array}\end{array}$ & $\begin{array}{c}\text { e ISSN : 2581-1126 } \\
\text { p ISSN : 2442-448X }\end{array}$ & Vol 6, No: 3 & Hal: 202 - 215 & Desember 2019 \\
\hline
\end{tabular}

hanyalah untuk menyelesaikan permasalahan yang bersifat sesaat.

Dampak terhadap kesejahteraan masyarakat hamper tidak terasa. Demikian juga dampak terhadap perusahaan tidak dirasakan. Sedangkan jika ditinjau dari sisi dana memerlukan dana yang besar. Pada akhirnya corporate charity ini untuk saat ini sangat jarang dilakukan, karena selain dana yang diperlukan sangat besar juga dampaknya tidak terlihat secara nyata dalam jangka panjang.

\section{Corporate Philanthropy}

Corporate Philanthropy ini merupakan CSR yang dilakukan oleh perusahaan dengan motif dasar pada kemanusiaan yang mempunyai sumber dari etika dan norma yang berlaku universal. Norma dan etika universal tersebut yaitu keinginan dari setiap manusia untuk menolong sesamanya. Kegiatan CSR yang dilandasi motif corporate philanthropy ini bersifat parsial dengan dasar memberikan sebagian keuntungan yang diperoleh perusahaan sebagai timbale balik dari perusahaan yang telah memanfaatkan sumber daya yang ada dalam masyarakat. Kegiatan CSR ini hanyalah kewajiban moral dimana perusahaan telah mengambil dan memanfaatkan sumber daya yang ada. Hampir sama dengan charity, Philanthropy ini juga tidak mempunyai dampak dalam jangka panjang. Corporate Philanthtopy bisa juga diartikan sebagai inisiatif perusahaan untuk terlibat dalam upaya-upaya perbaikan kehidupan sosial.

\section{Corporate Citizenship}

Corporate Citizenship merupakan program CSR yang didasarkan pada motif kewargaan dengan tujuan untuk mencapai kemakmuran demi kepentingan semua. Dampak dari corporate citizenship ini bersifat jangka panjang baik bagi perusahaan maupun masyarakat. $\mathrm{Hal}$ ini disebabkan karena kegiatan CSR dengan matif ini telah dirancang sedemikian rupa sehingga akan tercipta kemandirian dan keberdayaan dari masyarakat dengan tetap memperhatian keberlanjutannya (Saidi dan Abidin 2004).

Terdapat bentuk-bentuk CSR yang dilakukan oleh perusahaan, dintaranya adalah:

\section{Bantuan Sosial (Social Assisntence)}

Bantuan social merupakan bentuk CSR yang paling sederhana.

Bantuan social adalah kegiatan memberikan bantuan social kepada masyarakat sebagai implementasi dari prinsip filantropi yang dimiliki oleh perusahaan. Bantuan social didasarkan pada asas kemanusiaan dan keinginan untuk membantu sesama.

Bantuan social dilakukan oleh perusahaan bersifat parsial, karena kegiatan bantuan social bersifat satu arah, yaitu perusahaan membantu masyarakat, tanpa adanya keterlibatan masyarakat lebih jauh selain menerima bantuan yang diberikan oleh perusahaan.

2. Hubungan Masyarakat (Community Relations) Hubungan masyarakat merupakan bentuk CSR yang lebih banyak dilakukan oleh divisi public relation (humas) yang ada dalam suatu perusahaan.

Hubungan masyarakat merupakan bentuk CSR yang bertujuan untuk menjalin hubungan baik antara perusahaan dengan masyarakat.

Kegiatan hubungan masyarakat ini harus bersifat srategis dengan wujud nilai-nilai sebagai berikut :

a. Secara mendasar menunjukkan nilai-nilai dan misi perusahaan

b. Bersifat proaktif buka reaktif

c. Memiliki visi dan tujuan yang jelas

d. Didasari pengembangan program yang substantif

e. Melakukan pemantauan, pengukuran, dan evaluasi 
Prosiding Penelitian \&

Pengabdian Kepada

Masyarakat e ISSN : $2581-1126$

p ISSN : 2442-448X
Vol 6, No: 3

Hal: $202-215$

Desember 2019

f. Mengharapkan bisa menghasilkan outcome dan dampak

g. Memiliki fokus yang terumuskan (Yosal I riantara, 2007).

Salah satu bentuk dari CSR adalah pengembangan masyarakat yang merupakan model dari pembangunan komunitas dengan tujuan untuk menjadikan komunitas menjadi mandiri dan berdaya.

Pengembangan masyarakat merupakan program yang disusun oleh perusahaan untuk meningkatkan pertumbuhan ekonomi, keadaan lingkungan, pendidikan, keahlian, kesehatan, dan kesejahteraan dari stakeholder perusahaan, terutama bari mereka yang tinggal berdekatan atau dipengaruhi oleh kegiatan perusahaan (Nigam, 1999).

Selain itu pengembangan masyarakat sebagai salah satu bentuk dari CSR yang saat ini banyak dikembangkan mempunyai prinsipprinsip tertentu. Ife mengemukakan prinsipprinsip pengembangan masyarakat sebagai berikut:

\section{Integrated Development}

Kegiatan pengembangan masyarakat harus merupakan sebuah pembangunan yang terintegrasi, yang dapat mencakup berbegai aspek kehidupan manusia

\section{Human Right}

Kegiatan pengembangan masyarakat harus dapat menjamin adanya pemenuhan hak bagi setiap manusia untuk hidup secara layak dan baik

\section{Sustainability}

Kegiatan pengembangan masyarakat tidak hanya untuk kepentingan sesaat, namun harus memperhatikan sifat keberlanjutan dari kegiatan yang dilaksanakan

\section{Empowerment}

Pemberdayaan merupakan tujuan dari pengembangan masyarakat. Pemberdayaan mengandung pengertian menyediakan sumbersumber, kesempatan, pengetahuan, dan ketrampilan kepada masyarakat untuk meningkatkan kapasitasnya agar dapat menentukan masa depannya dan dapat berpartisipasi dalam kehidupan masyarakat dan mempengaruhi kehidupan masyarakat

\section{Self-Reliance}

Kegiatan pengembangan masyarakat sedapat mungkin memanfaatkan berbagai sumber yang dimiliki oleh masyarakat daripada menggantungkan kepada dukungan dari luar

\section{Organic Development}

Kegiatan Pengembangan masyarakat merupakan proses yang kompleks dan dinamis, dan masyarakat juga mempunyai sifat yang organic.

Oleh sebab itu penyelesaian msalah yang ada dalam masyarakat sepenuhnya ditentukan oleh kondisi dan situasi masyarakat itu sendiri

\section{The Integrity of Process}

Pengembangan masyarakat bukan hanya Mementingkan pencapaian hasil, melainkan proses

\section{Co-operation}

Pengembangan masyarakat lebih membutuhkan struktur yang kooperatif

\section{Participation}

Pengembangan Masyarakat sedapat mungkin memaksimalkan partisipasi masyarakat, dengan tujua agar setiap orang dapat terlibat secara aktif dalam aktivitas dan proses masyarakat. Partisipasi Ini juga harus didasarkan kepada kesanggupan masing-masing anggota masyarakat.

CSR di Indonesia saat ini banyak mendapatkan perhatian dari banyak lapisan masyarakat maupun pemerintah. Kementerian lingkungan hidup telah tegas menggunakan parameter kepedulian perusahaan terhadap masyarakat, sebagai salah satu kriteria penilaiannya. Dalam proper kementerian lingkungan hidup misalnya, 


\begin{tabular}{|c|c|c|c|c|}
\hline $\begin{array}{c}\text { Prosiding Penelitian \& } \\
\begin{array}{c}\text { Pengabdian Kepada } \\
\text { Masyarakat }\end{array}\end{array}$ & $\begin{array}{c}\text { e ISSN : 2581-1126 } \\
\text { p ISSN : 2442-448X }\end{array}$ & Vol 6, No: 3 & Hal: $202-215$ & Desember 2019 \\
\hline
\end{tabular}

CSR atau community development perusahaan merupakan salah satu aspek penting yang dinilai. Program CSR atau yang dikenal dengan tanggung jawab sosial perusahaan sebagai sebuah kepedulian organisasi bisnis bertindak dengan cara mereka sendiri dalam melayani kepentingan organisasi dan kepentingan publik eksternal (Schermerhorn dalam Suharto, 2007). Secara konseptual, CSR merupakan sebuah pendekatan di mana perusahaan mengintegrasikan kepedulian sosial dalam operasi bisnis dan interaksi mereka dengan pemangku kepentingan berdasarkan prinsip kesukarelaan dan kemitraan (Suharto, 2007).

Pengembangan masyarakat merupakan upaya mengembangkan sebuah kondisi masyarakat secara berkelanjutan dan aktif berlandaskan prinsip-prinsip keadilan sosial dan saling menghargai. Selain itu pengembangan masyarakat juga diartikan sebagai komitmen dalam memberdayakan masyarakat lapis bawah sehingga masyarakat memiliki berbagai pilihan nyata menyangkut masa depan mereka. Secara garis besar terdapat empat prinsip pengembangan masyarakat yaitu:

- Pengembangan masyarakat menolak pandangan yang tidak memihak pada sebuah kepentingan (disinterest). Pada prinsip ini pengembangan masyarakat berupaya untuk menampakkan nilainilai dan mengartikulasikannya secara jelas. Pada prinsip ini pengembangan masyarakat berkomitmen pada masyarakat miskin dan keadilan sosial, hak asasi manusia dan kewarganegaraan, pemberdayaan dan penentuan diri sendiri, tindakan kolektif dan keanekaragaman.

- Mengubah dan terlibat dalam konflik. Pengembangan masyarakat bertujuan untuk mengubah struktur yang diskriminatif, memaksa dan menindas di masyarakat. Untuk mencapai tujuan ini pengembangan masyarakat membangkitkan, menghadirkan informasi yang tidak menyenangkan dan kadang-kadang mengganggu. $\mathrm{Di}$ sini pengembangan masyarakat melengkapi 23 kegiatannya dengan gerakan sosial yang baru seperti hak asasi manusia dan gerakan perdamaian.

- Membebaskan, membuka masyarakat dan menciptakan demokrasi partisipatori. Pembebasan atau liberasi adalah reaksi penentangan terhadap bentuk-bentuk kekuasaan, perbudakan dan penindasan. Pembebasan menuntut pemberdayaan dan otonomi. Pembebasan melibatkan perjuangan menentang dan membebaskan dari orang-orang, idiologi, dan struktur yang sangat berkuasa.

- Kemampuan mengakses terhadap programprogram pelayanan kemasyarakatan. Pengembangan masyarakat menempatkan program-programnya dilokasi yang strategis dapat diakses oleh masyarakat. Lingkungan fisik yang dicipatakan melelui pengembangan masyarakat memiliki suasana yang bersahabat dan informal, bukan suasana birokratis, formal dan tertekan

Program-program pengembangan masyarakat secara umum dimaksudkan untuk meningkatkan kualitas hidup masyarakat lapis bawah. Pengembangan masyarakat secara umum diaktualisasikan dalam beberapa tahapan mulai dari perencanaan, pengkoordinasian dan pengembangan berbagai langkah penanganan program kemasyarakatan. Program pengembangan masyarakat umumnya yang menekankan penerapan community-based management (CBM). Yaitu pendekatan pengelolaan program yang menjadikan pengetahuan dan kesadaran masyarakat lokal sebagai dasarnya. CBM diartikan sebagai suatu strategi untuk mewujudkan praktik pembangunan yang berpusat pada manusia, pusat pengambilan keputusan mengenai pemanfaatan sumberdaya secara berkelanjutan di suatu daerah berada di tangan organisasiorganisasi dalam masyarakat di daerah tersebut. Masyarakat diberikan kesempatan dan tanggung jawab dalam melakukan pengelolaan terhadap sumber daya yang dimilikinya. Mereka sendiri yang mendefinisikan kebutuhan, tujuan, aspirasi dan membuat keputusan demi 


\begin{tabular}{|c|c|c|c|c|}
\hline $\begin{array}{c}\text { Prosiding Penelitian \& } \\
\begin{array}{c}\text { Pengabdian Kepada } \\
\text { Masyarakat }\end{array}\end{array}$ & $\begin{array}{c}\text { e ISSN : 2581-1126 } \\
\text { p ISSN : 2442-448X }\end{array}$ & Vol 6, No: 3 & Hal: $202-215$ & Desember 2019 \\
\hline
\end{tabular}

mencapai kesejahteraan yang diimpikan. Kebanyakan pekerja sosial menyusun kegiatan pengembangan masyarakat melalui beberapa langkah secara bertahap sesuai kondisi dan kebutuhan masyarakat yang menjadi sasaran kegiatan. Ada enam tahap dalam melakukan perencanaan program diantaranya yaitu: Pertama, tahap problem posing (pemaparan masalah) yang dilkukan aktivis dengan mengelompokkan dan menentukan masalahmasalah serta persoalan-persoalan yang dihadapi masyarakat dari kelompok sasaran. Masyarakat pada umumnya menyadari permasalahan yang dihadapi. Namun, hal itu tidak diungkapkan. Peran pekerja sosial dalam tahapan ini adalah memberi penjelasan, informasi dan memfasilitasi kegiatan musyawarah atau diskusi diantara warga dari kelompok sasaran. Kedua, tahap problem analysis (analisis masalah). Tahap ini pekerja sosial mengumpulkan informasi mulai dari jenis, ukuran, dan ruang lingkupan permasalahanpermasalahan yang dihadapi warga dan menjadikan informasi tersebut dapat diakses oleh pihak-pihak yang berkepentingan. Ketiga, tahap penentuan tujuan (aims) dan sasaran (objectives). Tujuan menunjuk pada visi, tujuan jangka panjang, dan statement tentang petunjuk umum. Contoh visi pengembangan masyarakat yang dirumuskan oleh pekerja sosial adalah pembentukan masyarakat dimana seluruh warganya terlibat secara aktif dalam program untuk mempertahankan sistem lingkungan dan membuat faktor sosial, ekonomi dan politik yang ada dapat menjamin persamaan secara maksimal dikalangan warga untuk mendapatkan kebutuhan-kebutuhan dasar dan pelayanan. Sementara sasaran lebih bersifat khusus dibandingkan tujuan. Pekerja sosial menetapkan apa yang menjadi kepercayaan dan apa yang akan dicapai kemudian menyusun proses dan tugas-tugas khusus. Sasaran yang ditetapkan terdiri atas kegiatankegiatan yang dapat di identifikasi, dianalisis dan dapat diungkapkan secara jelas kepada warga. Sasaran mungkin berjangka panjang, menengah dan pendek. Sasaran jangka panjang secara umum menuntut sejumlah strategi berbeda-beda dan sering disusun dalam berbagai tahap. Sasaran jangka menengah dan pendek berskala lebih kecil lagi.untuk mamahami tujuan dan sasaran jangka panjang, menengah dan pendek dipahami dari sesuatu yang luas ke spesifik, dari yang abstrak ke kongkrit. Keempat, tahap action plans (perencanaan tindakan). Tahap ini dilakukan oleh pekerja sosial dengan kegiatan perencanaan berbagai aksi untuk mencapai tujuan. Dalam merencanakan aksi, pekerja sosial memerhatikan tenaga kerja, peralatan, jaringan sosial, dana, tempat, informasi, waktu tersedia, faktor-faktor penghambat, faktorfaktor pendukung, permasalahan-permasalahan stakeholder, tugas-tugas nyata yang dilakukan, pihak-pihak berpengarauh secara signifikan terhadap hasil, pemein-pemain kunci baik secara individual dan kelompok, dilema atau kontradiksi atau ketegangan antara alat dengan tujuan dan hasil-hasil yang mungkin dicapai. Kelima, tahap pelaksanaan kegiatan. Tahap ini dilakukan oleh pekerja sosial dengan mengimplementasikan langkah-langkah pengembangan masyarakat yang telah dirancang. Para aktivis ketika berada dalam tahapan ini dituntut untuk memperhatikan konsekuensi yang mungkin timbul sebagai akibat dari aksi yang dilakukan. Keenam, tahap evaluasi yang dilakukan oleh pekerja sosial secara terus menerus, baik secara formal maupun semi formal pada akhir proses pengembangan masyarakat maupun secara informal dalam setiap bulan, mingguan, dan bahkan harian.

Wujud nyata hubungan antara perusahaan dengan lingkungan komunitasnya dalam kaitannya dengan etika bisnis yang dilaksanakan merupakan salah satu bentuk tanggung jawab sosial perusahaan. Bentuk tanggung jawab perusahaan sebagai salah satu etika yang tampak, dapat dijabarkan dalam bentuk aktivitas dari perusahaan yang lainnya, seperti program pembangunan komunitas, yang dapat pula dijabarkan dalam bentuk hubungan komunitas, pelayanan komunitas, dan 


\begin{tabular}{|c|c|c|c|c|}
\hline $\begin{array}{c}\text { Prosiding Penelitian \& } \\
\begin{array}{c}\text { Pengabdian Kepada } \\
\text { Masyarakat }\end{array}\end{array}$ & $\begin{array}{c}\text { e ISSN : 2581-1126 } \\
\text { p ISSN : 2442-448X }\end{array}$ & Vol 6, No: 3 & Hal: 202 - 215 & Desember 2019 \\
\hline
\end{tabular}

pemberdayaan komunitas (Rudito dan Melia, 2007:18). Di wilayah pedesaan Sumatera Selatan yang berdekatan dengan wilayah operasi kegiatan yang di lakukan oleh perusahaan migas, kebanyakan penduduknya bergantung pada sektor pertanian (agraris) dan masih menghadapi persoalan kemiskinan. Kondisi ini telah mendorong masyarakat untuk menuntut perusahaan agar dapat menyerap tenaga kerja lokal.

Tetapi banyak kendala yang dihadapi oleh perusahaan seperti tingkat pendidikan dan keterampilan penduduk desa sangat rendah, sehingga mereka hanya diterima pada level pekerjaan harian seperti menjaga sumur migas, dan tenaga kerja keamanan. Padahal dalam bidang migas membutuhkan tenaga kerja yang mempunyai keahlian dan keterampilan dalam pendidikan yang tinggi. Kesenjangan dalam perekrutan tenaga kerja ini menimbulkan dilema bagi kelangsungan perusahaan, dalam satu sisi perusahaan berusaha untuk membantu penduduk lokal untuk mendapatkan tenaga kerja lokal, di sisi lain tingkat keahlian pekerja lokal dan keterampilannya sangat rendah.

Kondisi ini berimbas kepada tuntutan masyarakat desa untuk menekan perusahaan sebagai bagian dari kompensasi bagi perusahaan yang telah menggali potensi sumber daya alam di wilayah mereka. Hal ini terungkap dari hasil penelitian yang dilakukan oleh Al Fitri, Yenrizal dan Imron Hakim (2002). Sebagian besar masyarakat menganggap bahwa kekayaan migas yang dikelola oleh perusahaan harus diimbangi dengan peningkatan kesejahteraan masyarakat dan penghasilan, salah satunya dengan bekerja di perusahaan. Oleh sebab itu, masyarakat sekitar perusahaan menuntut perusahaan agar dapat diterima bekerja di perusahaan. Kondisi dilematik tersebut direspon oleh perusahaan dengan menempatkan program communtiy development sebagai tanggung jawab sosial perusahaan terhadap masyarakat sekitar wilayah operasi. I mplementasi lapangan masih terjebak dengan pemberian bantuan atau charity terhadap masyarakat, sehingga banyak program yang kurang efektif dalam merubah dan memperbaiki tingkat penghasilan dan taraf kesejahteraan masyarakat. Pelaksanaan program community development masih bersifat charity dan belum menyentuh kemandirian masyarakat. Ha ini diperkuat oleh studi pendahuluan yang ternyata pelaksanaan program community development masih didominasi oleh pemberian bantuan kepada masyarakat berupa materi dan dana, sehingga menimbulkan ketergantungan kepada pihak perusahaan. Pemberian charity memang cukup efektif dalam jangka pendek. Namun untuk jangka panjang kurang dapat dipertahankan, mengingat kebutuhan hidup masyarakat semakin terdesak. Apalagi kondisi hutan yang selama ini menjadi sumber kehidupan menjadi sangat terbatas. Hal tersebut dapat menimbulkan konflik antara perusahaan dan masyarakat sekitar wilayah operasi. Kurangnya kepedulian perusahaan dalam menjalankan community development di Indonesia menajdi fenomena menarik untuk diamati. Tentunya untuk mengetahui tentang pemahaman atas tanggung jawab sosial, perusahaan di Indonesia perlu melakukan tulisan empiris. Oleh karena itu, studi tentang pengembangan masyarakat di wilayah perlu dilakukan. Penguatan modal sosial, terutama nilai lokal dan jaringan masyarakat lokal dikembangkan dalam pendekatan model pengembngan masyarakat lokal. Program pengembangan masyarakat harus dapat mendorong partisipasi masyarakat, perencanaan sosial terpadu, dan penguatan modal sosial dalam penerapan program CSR. Hal ini penting karena selama ini pendekatan pengembangan masyarakat lebih banyak dilakukan secara top down dan mengadopsi konsep umum yang cenderung seraga, sehingga dibutuhkan perpaduan konsep umum dengan konsep lokal dalam membangun model pendekatan yang cocok untuk masyarakat setempat. Peningkatan kesejahteraan masyarakat di sekitar lokasi penambagnan migas menjadi indikator tercapainya kemandirian sosial ekonomi melalui program pengembangan masyarakat. 


\begin{tabular}{|c|c|c|c|c|}
\hline $\begin{array}{c}\text { Prosiding Penelitian \& } \\
\begin{array}{c}\text { Pengabdian Kepada } \\
\text { Masyarakat }\end{array}\end{array}$ & $\begin{array}{c}\text { e ISSN : 2581-1126 } \\
\text { p ISSN : 2442-448X }\end{array}$ & Vol 6, No: 3 & Hal: $202-215$ & Desember 2019 \\
\hline
\end{tabular}

\section{Kegiatan CSR Pengembangan Masyarakat PT. PERTAMI NA di Desa Pangkalan Babat, Kecamatan Rambang Dangku, Muara Enim Sumatera Selatan (Betalang).}

Lazimnya permukiman warga di Sumatera Selatan, pemukiman di desa Pangkalan Babat juga terbentuk dari proses betalang. Awalnya wilayah ini menjadi lokasi berkebun masyarakat atau dalam istilah setempar disebut dengan kebiasaan Betalang. Talang adalah kebun milik yang dibuka sendiri. Di talang ini biasanya didirikan pondok untuk tempat beristirahat seusai berkebun. Penduduk kerap menginap di talang jika kebun belum bisa ditinggalkan. Misalnya awal masa tanam atau masa pembersihan. Nama Pangkalan Babat berasal dari istilah kebun warga proses warga warga yang membuka untuk menebas atau membabat yang menggunakan alat parang untuk membabat rumput. Karena wilayah ini agak berbeda dengan wilayah lainnya, yaitu terdiri dari daratan dan rawa pasang surut, maka warga yang membuka lahan harus dengan membabat rumput. Istilah ini yang kemudian berkembang menjadi Pangkalan Babat. Secara geografis, désa ini memiliki luas 522 hektar. Wilayah ini terbagi 2 dusun dengan posisi berbeda persis di pinggir aliran Sungai Lematang, salah satu anak sungai yang bermuara ke sungai Musi. Desa Pangkalan Babat masuk Kecamatan Rambang Dangku, Kabupaten Muara Enim.

Pemukiman warga mengelompok pada satu kawasan dengan dihubungkan oleh lorong kecil. Warga desa ini adalah penduduk asli etnis Rambang. Umumnya perubahan warga berbentuk rumah panggung dengan arsitektur khas Sumatera Selatan. Jarak antar rumah tidak terlalu rapat, yaitu sekitar $5 \mathrm{~m}$ antar rumah. Rumah di desa ini tidak mengenal pagar yang menampilkan hubungan yang dekat antar warga. Struktur pemukiman warga yang terbuka dan mengelompok memperlihatkan kemungkinan hadirnya pendatang. Desa ini memiliki kantor desa namun aktivitas pemerintah banyak berlangsung di rumah kepala desa. Rumah kepala desa mempunyai akses yang memadai. Kegiatan administrasi dijalankan oleh sekretaris desa, sementara kepala desa berfungsi sebagai penanggung jawab dan pengambil kebijakan. Aktivitas organisasi di desa berjalan dengan baik. Kegiatan administrasi di desa ini pun terstruktur dan rapih. Unit atau organisasi dalam struktur desa ini menjalankan fungsinya dengan baik. Berjalannya administrasi desa terlihat dari mekanisme laporan pertanggungjawaban kepala desa yang dibuat secara rutin.

Dilihat dari posisinya, desa ini termasuk desa yang strategis. Desa ini merupakan perlintasan bagi warga sekitar yang ingin ke Desa Baturaja. Di desa ini terdapat sebuah dermaga penyebrangan bagi warga yang ingin menyeberang. Hasil ini kemudian menjadi pemasukan utama bagi Desa Pangkalan Babat untuk menambah pendapatan desa. Pemerintah desa kemudian membuat badan usaha milik desa (BUMD) yang khusus mengelola sarana angkutan penyeberangan dengan getek air. Dari sinilah pemasukan kas desa bisa dipenuhi untuk biaya operasional desa sehari-hari. Untuk tahun 2008, pendapatan BUMD ini mencapai 6 juta rupiah keuntungan bersih. Selain itu, di desa ini juga terdapat sumur minyak Pertamina. Oleh karenanya, keterkaitan Pertamina dengan desa ini cukup kuat. Interaksi perusahaan dengan desa juga kerap terjadi.

Berdasarkan jenis kelaminnya, jumlah penduduk laki-laki di desa ini adalah 433, sedangkan perempuannya berjumlah 570 orang. Penduduk desa ini umumnya adalah etnis lokal, atau yang disebut marga Dangku. Karenanya, hubungan kekerabatan antar warga sangat dekat dan umumnya mempunyai ikatan darah. Penduduk yang tergolong usia produktif dan merupakan angkatan kerja di desa ini cukup banyak. Warga ini berusia dari rentang 16 tahun-50 tahun. Jumlahnya mencapai 700 orang lebih. Kelompok inilah yang termasuk angkatan kerja. Jumlah tersebut disalurkan pada bidang pertanian dan usaha lain yang ada di desa. Sebagian lagi berusaha dengan mencari 


\begin{tabular}{|c|c|c|c|c|}
\hline $\begin{array}{c}\text { Prosiding Penelitian \& } \\
\begin{array}{c}\text { Pengabdian Kepada } \\
\text { Masyarakat }\end{array}\end{array}$ & $\begin{array}{c}\text { e ISSN : 2581-1126 } \\
\text { p ISSN : 2442-448X }\end{array}$ & Vol 6, No: 3 & Hal: 202-215 & Desember 2019 \\
\hline
\end{tabular}

mata pencaharian baru di luar desa. Untuk angka pengangguran, tidak diperoleh data yang jelas karena memang semua warga pada dasarnya adalah petani dan pekerja. Kendatipun mereka tidak memiliki ladang ataupun kebun, mereka terbiasa dengan bekerja pada orang lain. Artinya tidak ada yang dikatakan menganggur murni tanpa ada usaha apapun. Mata pencaharian utama warga adalah petani Palawija (90\%). Tanaman Palawija memang menajdi andalan karena memang kondisi lahan yang terbatas. Wilayah desa yang berada di pinggiran Sungai Lematang membuat sebagian besar lokasi desa ini terendam oleh air ketika musim pasang. Hal ini terjadi setiap tahun selama sekitar 3 bulan lamanya. Pada masa ini tidak ada yang bisa dilakukan oleh warga kecuali menunggu air surut. Selama musim itu, aktivitas warga lebih banyak di rumah, sebagian memancing dan mencari ikan di sungai. Setelah itu, selepas musim air pasang, barulah warga memulai membuka lahan yang ada untuk diolah menjadi ladang Palawija. Jenis Palawija yang ditanam adalah mentimun, jagung, buncis, terong, dan kacang-kacangan.

Hampir semua penduduk di desa ini bertanam tanaman Palawija. Sebanyak 274 rumah tangga petani, sebanyak $80 \%$ punya lahan sendiri, tetapi sesuai karakteristik tanaman Palawija, maka luas lahan yang mereka miliki sangat terbatas. Rata-rata tiap orang memiliki lahan antara 0,25 Hektar - 1 Hektar. Hanya sebagian kecil (sekitar 14 orang) yang punya lahan lebih dari satu hektar. Lahan tersebut diolah oleh warga dengan pola tanam yang sifatnya saling bergantian. Sejauh ini, hasil pertanian Palawija ini cukup menjanjikan dan bisa menjadi mata pencaharian utama warga. Untuk tanaman mentimun misalnya, dalam wilayah satu hektar bisa dipanen mencapai 30 ton terhitung dari sejak mulai panen hingga panen akhir. Untuk buncis bisa mencapai 25 ton setiap hektar, terong mencapai 5 ton setiap hektar. Tidak mengherankan, pada saat musim tanam tiba, wilayah desa Pangkalan Babat akan menghijau dengan sayuran dan hasilnya melimpah di sekitar desa.
Selain andalan pada tanaman pawija, warga juga mengandalkan kegiatan mencari ikan di sungai dan elbak yang banyak di sekitar desa. Sebagian kecil warga menjadikan ini sebagai mata pencaharian utama, walaupun di beberapa daeah mereka juga menanam Palawija. Mata pencaharian lain yang saat ini sedang coba diusahakan oleh warga adalah berkebun jeruk manis.di sisi lain, atas bantuan Pertamina, telah ditanam pula tanaman mangga di sekitar pekarangan warga. Sekitar 2 tahun lagi, mangga akan mulai panen dan menjadi salah satu sumber mata pencaharian baru bagi warga.

Kelompok kepentingan baik formal maupun informasi terlihat tidak menonjol di desa ini. Hal ini karena pengaruh kuat tokoh masyarakat dan struktur sosial kemasyarakatan yang memang memiliki hubungan persaudaraan yang kuat. Struktur sosial ini terlihat dari kedekatan, kekerabatan serta mekanisme perekonomian tradisional yang berjalan dengan baik. Persaingan antar kelompok yang mengarah pada kepentingan tertentu masuknya perusahaan yang berinvestasi di wilayah mereka tidak terlihat. Hal ini depengaruhi oleh hubungan kekerabatan yang sangat dekat sehingga tidak adanya kecurigaan antar warga. Faktor lain yang berpengaruh terhadap keterbukaan masyarakat kepada pendatang, serta perekonomian warga yang cukup berjalan dengan baik. Kelompok masyarat tidak terbentuk secara jelas karena adanya peran tokoh masyarakat yang sangat di percaya oleh masyarakat. Kelompok ini mampu mengorganisir masyarakat dan meredam gejolak yang mungkin muncul di dalam masyarakat. Kepemimpinan kepala desa saat ini memang menjadi faktor kunci kondisi sosial kemasyarakatan yang bai dan aman. Pola kepemimpinan sangat tegas dan mendahulukan kepentingan umum.

Sarana infrastruktur fisik desa Pangkalan Babat dapat dikatakan memadai. Jalur perlintasan utama yang cukup jauh dari pusat kecamatan, namun sarana dan prasarana sudah memadai. Kondisinya pun masih bagus dan 


\begin{tabular}{|c|c|c|c|c|}
\hline $\begin{array}{c}\text { Prosiding Penelitian \& } \\
\begin{array}{c}\text { Pengabdian Kepada } \\
\text { Masyarakat }\end{array}\end{array}$ & $\begin{array}{c}\text { e ISSN : 2581-1126 } \\
\text { p ISSN : 2442-448X }\end{array}$ & Vol 6, No: 3 & Hal: 202 - 215 & Desember 2019 \\
\hline
\end{tabular}

dapat berfungsi dengan baik. Warga selalu melakukan perawatan atas fasilitas yang ada. Sarana keagamaan hanya untuk kalangan muslim karena memang penduduk desa ini umumnya beragama muslim.

Sarana kesehatan di desa ini masih terbatas. Namun kendati demikian warga masih bisa menggunakan trasPortasi untuk menjangkau kesehatan yang lebih layak. Dan tidak sedikit warga yang sudah mempunyai kendaraan sendiri. Fasilitas jalan terlihat baik. Dan jembatan terdapat jalan yang dikendaraan. Ini merupakan sarana utama warga untuk keluar masuk desa.

Sarana angkutan sungai getek yang dimiliki desa menajadi sarana transfortasi utama bagi warga untuk ke desa Baturaja. Hal ini menjadi jalan warga untuk menuju pasar dan menuju wilayah desa lain. Selain itu getek ini menjadi sarana pemasukan utama bagi desa dalam menambah pendapatan. Sumur bor merupakan bantuan dari pertamina yang digunakan untuk kepentingan umum desa ini. Sarana ini kemudian ditempatkan di beberapa posisi stetrategis, dan menjadi kewajiban bagi warga yang menggunakan fasilitas tersebut untuk memelihara dan menjaganya dengan baik. Potensi utama yang bisa dikembangkan adalah perternakan sapi, kambing dan memerlihara ikan di kolam. Potensi ini terlihat karena adanya sarana pendukung tersedianya rumput untuk makanan dan kayu untuk kandang. Adapun saluran air untuk pengairan ikan. Hanya saja perlu adanya metode untuk warga yang belum terbiasa dengan perternakan. Di beberapa lokasi sangat dimungkinkan untuk perternakan ikan, selain itu potensi perkebunan lain adalah pemanfaatan lahan pekaranga, seperti mangga, yang sudah dilakuan dalam program community develoment. Sektor pendidikan di desa ini, tergambar dari fasilitas yang dimiliki. Desa ini memiliki satu SDN kondisi tersebut masih terbatas dan belum memadai. Sementara untuk melanjutkan ke tingkat yang beih tinggi harus ke daerah lain yang cukup jauh dari desa. Kondisi desa tidak memiliki sarana transfortasi umum dan tidak mungkin terjangkau ke lokasi tersebut. Oleh karenanya kondisi pendidikan warga masih sangat rendah. Persoalan di bidang pendidikan masih menjadi yang utama karena fasilitasnya, terutama untuk sekolah lanjutan. Hal ini menyulitkan warga untuk dapat melanjutkan pendidikan, sehingga tidak sedikit warga yang hanya selesai pada tingkat SDN. Tetapi terdapat pula warga yang menyekolahkan anaknya pada tingkat yang lebih tingga bahkan hingga perguruan tinggi.

Tanggapan dan partisipasi masyarakat dalam pelaksanaan program CSR tersbut menjadi penentu utama dari indeks keberhasilan program, terutama pada program yang berbasis pengembangan ekonomi mandiri dan pemberdayaan masyarakat. Partisipasi dan inisiatif dari masyarakat secara penuh dan adanya sinergi antara dua pihak dapat menjadi faktor optimalisasi pelaksanaan program. Menurut Ardianto (2011) adanya partisipasi masyarakat sebagai pemicu kemandirian dan proses pemberdayaan adalah komponen yang sangat penting. Proses tersebut dilakukan secara akumulatif sehingga semakin banyak keterampilan, atau semakin tingginya kompetensi yang dimiliki seseorang maka semakin tinggi kemampuannya berpartisipasi.

\section{PENUTUP}

Pemberdayaan masyarakat (community empowerment) menjadi isu utama dalam program dan orientasi pembangunan nasional pada saat ini. Kegiatan peningkatan sarana jalan diupayakan melibatkan masyarakat secara aktif melalui pemberdayaan masyarakat. Pemberdayaan masyarakat adalah komitmen dalam memberdayakan masyarakat lapis bawah sehingga mereka memiliki berbagai pilihan nyata yang menyangkut masa depannya. Perseroan yang menjalankan kegiatan usahanya di bidang dan/atau berkaitan dengan sumber daya alam diwajibkan untuk menyelenggarakan program tanggung jawab sosial dan lingkungan dengan tujuan menciptakan hubungan yang serasi antara korporasi dengan masyarakat. Sehingga 
kebradaan perusahaan dalam suatu wilayah memberikan kontribusi bagi kemajuan ekonomi dan sosial masyarakat di sekitar perusahaan. Perusahaan yang mengelola sumber daya alam berpotensi menimbulkan kerusakan yang tidak mudah dipulihkan, maka kegiatan yang memberikan penggantian atas kerusakan merupakan hal yang harus dilakukan oleh perusahaan tersebut. Program dan kegiatan yang merupakan implementasi tanggung jawab sosial dan lingkungan tersebut harapannya tidak akan menempatkan masyarakat dalam penderitaan sebagai akibat tetap tergantungnya masyarakat terhadap alam yang sudah rusak karena terkurasnya sumber daya alam oleh perusahaan.

Kegiatan CSR dapat berjalan bersamaan untuk mencapai pertumbuhan yang berkesinambungan. Sejalan dengan visi untuk memberi kehidupan yang nyaman, PT PERTAMINA senantiasa berkontribusi positif bagi kehidupan Anda dan lingkungan sekitar. Serta CSR merupakan bagian dari pelaksanaan Tata Kelola Perusahaan yang Baik (GCG), merupakan kesadaran global terhadap pentingnya menerapkan praktik CSR yang baik, meningkatnya perhatian masyarakat luas terhadap etika dan akuntabilitas bisnis, serta ekspektasi yang terus berkembang terhadap perusahaan untuk turut membangun sinergi dan kolaborasi positif dengan masyarakat dalam rangka mencapai pertumbuhan bersama.

Tulisan ini dapat memberikan beberapa saran atas hasil analisis terhadap implementasi program CSR :

- Mengevaluasi penerapan CSR PT Pertamina secara objektif

- Menjadi bahan referensi untuk kepentingan akademik, khususnya untuk Program Studi Kesejahteraan Sosial

- Menjadi referensi untuk perusahaan lainnya yang hendak melaksanakan program CSR sejenis

\section{UCAPAN TERI MA KASI H}

Penulis ucapkan terima kasih kepada dosen pemangku mata kuliah Corporate Social Responsibility; Bu Risna Resnawaty dan Pak Santoso Tri Raharjo yang telah menyampaikan materi dan insight yang sangat baik kepada penulis. Serta kepada semua tim penulis artikel yang telah bekerja sama dengan kooperatif di dalam penyusunan artikel ini.

\section{DAFTAR PUSTAKA}

\section{Kajian Pustaka}

A.B. Susanto, 2007. Corporate Social Responsibility, Jakarta: The Jakarta Consulting A Strategic Management Approach, CSR, Jakarta Consulting Group Publishing

Antonius Anton Lie. 2007. Kapital Sosial Dalam Organisasi Bisnis: Studi Kasus Klaim Asuransi Kendaraan Bermotor PT.Asia Krimere Polysindo di Jakarta.Disertasi. Depok: Universitas Indonesia.

Harry, Hikmat. 2003. Marginalisasi Komunitas Lokal dalam Perspektif Kontigensi Strategi Pemberdayan Masyarakat, Studi Kasus di Kota Bekasi. Disertasi. Bandung. Program Pascasarjana Universitas Padjadjaran

Masyarakat: Jurnal Sosiologi Edisi No.13 , 2004. Konflik Dalam Masyarakat Transisi. Depok: Labsosio FISIP UI .

Sulistoyani. 2004. Kemitraan dan Model-Model Pemberdayaan. Gava Media

Suparnyo, 2010, Corporate Social Responsibility Teory dan Praktek. Badan Penerbit Universitas Diponegoro.

Tahyuddin, Didi, Alfitri, \&Yenziral. 2001. Pemberdayaan Masyarakat di sekitar Kawasan Penambangan PT. Exspan Nusantara, di Provinsi Sumatera Selatan dan Provinsi Bangka Belitung. Indralaya: PT. Exspan Nusantara-Lembaga Penelitian Unsri. 


\begin{tabular}{|c|c|c|c|c|}
\hline $\begin{array}{c}\text { Prosiding Penelitian \& } \\
\begin{array}{c}\text { Pengabdian Kepada } \\
\text { Masyarakat }\end{array}\end{array}$ & $\begin{array}{c}\text { e ISSN : 2581-1126 } \\
\text { p ISSN : 2442-448X }\end{array}$ & Vol 6, No: 3 & Hal: $202-215$ & Desember 2019 \\
\hline
\end{tabular}

Yusuf Wibisono, 2007, Membedah Konsep \& Aplikasi CSR (Corporate Social Responsibility), PT Gramedia.

\section{Artikel IImiah}

Analisis Sosial Vol.10 No.1 April 2005. Perdebatan Konseptual Tentang Kaum Marginal. Bandung: Akatiga.

Analisis Sosial Vol.11 No. 1 April 2006. Tantangan Masa Depan Pertanian Indonesia. Bandung. Akatiga.

Analisis Sosial Vol.7 No. 2 Juni 2002. Demokratisasi dan Kemiskinan. Bandung. Akatiga.

Community Development J ournal. April 2005. Cultural Justicce, community dvelopment and onshore refugees in Australia. Louise Humpage and Greg Martson., Oxfort University Press

Community Development Journal.April 2005. Socia Capital or Social exclusion? The impactof asylum-seeker dispersal on UK refugee community organization. Roger Zetter, DavidGriffiths and Nando Sigona. Oxfort University Press.

Community Development J ournal. September 2005. Community Development is Europe. Gerrard Hautekeur. Oxfort University Press.

Damayanti, Melissa Ika. 2011. Pengaruh Pengungkapan Tanggung Jawab Sosial (Corporate Social Responsibility Disclosure) Terhadap Kepemilikan Institusional Pada Perusahaan Manufaktur di Indonesia. Skripsi. Universitas Diponegoro.

Herman, Kristina K. 2004. "Corporate Social Responsibility and Sustainable Development: The European Union Initiative as a Case Study", 11 Indiana J ournal Of Global Legal Studies.
Johan, Ardilla Mahardika. 2011. Faktor-Faktor yang Mempengaruhi Sifat Pengungkapan Sukarela Tanggung Jawab Sosial Perusahaan (Studi Empiris pada Perusahaan yang Terdaftar di Bursa Efek Indonesia). Skripsi. Universitas Diponegoro

Maria Ulfa. 2009. Pengaruh Karakteristik Perusahaan Terhadap Corporate

William, Cynthia A. 2002. "Corporate Social Responsibility in an Era of Economic Globalization.", 35 University of California Davis Law. 